\title{
CENTRAL EUROPEAN BOTANIC GARDENS AS CENTRES OF DISPERSAL OF ALIEN PLANTS
}

\author{
HALINA GALERA ${ }^{1}$, BARBARA SUDNIK-WÓJCIKOWSKA ${ }^{2}$ \\ ${ }^{1}$ Department of Plant Ecology and Environmental Conservation \\ University of Warsaw \\ Al. Ujazdowskie 4, 00-478 Warszawa, Poland \\ Botanic Garden-Center for Biological Diversity Conservation \\ of the Polish Academy of Sciences \\ Prawdziwka 2, 02-973 Warszawa, Poland \\ e-mail: h.galera@uw.edu.pl \\ 2 Department of Plant Ecology and Environmental Conservation, \\ University of Warsaw \\ Al. Ujazdowskie 4, 00-478 Warszawa, Poland
}

(Received: September 25, 2009. Accepted: February 3, 2010)

\begin{abstract}
The aim of the work was to estimate the specific role that Central European botanic gardens play in the dispersal of alien plants, which results from the wide variety of plants cultivated in the gardens and regular international exchange of plant material between these institutions.

We compared the results of recent field studies (in eight Polish botanic gardens) and a review of older literature data and herbarium collections (from Central European botanic gardens). We found that in Poland the proportion of botanic garden escapes was lower (3\%) than would be expected from the "tens rule". Botanic gardens have played a considerable role in the development of the synanthropic flora of Central Europe in the last 200 years. We determined a group of species introduced through a network of botanic gardens and propose 5 theoretical patterns to describe the mode and pathways of the early stages of introduction of these species.
\end{abstract}

KEY WORDS: garden escapes, migration patterns, plant invasions, synanthropic flora.

\section{INTRODUCTION}

Compared with other types of managed areas that are recognized as important distribution centres of alien plants (e.g. forest nurseries, urban green areas, private gardens and field crops), botanic gardens have a distinctive character (e.g. Sukopp 1990; Reichard and White 2001; Wittig 2002; Sukopp 2006). This is due to the fact that these institutions are open to the public and contain a wide variety of cultivated plants from different climatic zones, as well as to the regular international exchange of plant material between the gardens (Dawson et al. 2008). As a result of international cooperation (seed exchange mediated by Indices Seminum) useful and ornamental plants are introduced to botanic gardens, as well as species that are interesting in terms of morphology, biology, ecology and origin but not direct economic value.

Floristic studies of the vascular flora have frequently been conducted in botanic gardens. However, they have usually been concerned with one particular garden at a time (e.g. Evtjuchova 1949 - the flora and vegetation of the Main Moscow Botanic Garden, Adamczewska et al. 2000 the synanthropic flora of the Botanic Garden in Lodz, Borysiak et al. 2004 - the plant cover of the Poznan Botanic Garden and Graf, Rohner 1984; Sukopp 2006 - 2 botanic gardens in Berlin). Other floristic notes do not contain complete information about the flora of the gardens. To date there have been no comparative studies designed to investigate the role that botanic gardens play in the development of the European synanthropic flora. The problem was also noticed in Africa (Dawson et al. 2008). Such studies require the analysis of data obtained over large areas and collected over a considerable period of time. Therefore, it has often been necessary to analyse incomplete and scattered historical data (it is impossible to use quantitative historical data for comparisons). However they can provide valuable information about the past biological invasions.

In the present work we have combined the results of our observations made in Polish botanic gardens (Galera 2003; Galera and Sudnik-Wójcikowska 2004b) with a review of 
historical data (Galera and Sudnik-Wójcikowska 2004a floristic notes made mainly in Central European Botanic Gardens during the last 200 years). The study focused on the following questions:

1. Which are the species of weeds whose early stages of expansion were associated mainly with the activities of botanic gardens?

2. Are there any trends observed in the spontaneous spread of species in botanic gardens and their possible escape from cultivation into adjacent areas?

3. To what degree do plants cultivated in botanic gardens spread within its area in modern times?

\section{MATERIAL AND METHODS}

\section{Data gathering - recent records}

The current role that botanic gardens play as centres of dispersal of alien plants was assessed on the basis of studies carried out in eight botanic gardens in seven Polish cities (Bydgoszcz, Cracow, Lublin, Lodz, Poznan, Wroclaw and two gardens in Warsaw: Botanic Garden of University of Warsaw and Botanic Garden - Center for Biological Diversity Conservation of the Polish Academy of Sciences). The survey was conducted in the years 1992-1999 within a total area of $1.7 \mathrm{~km}^{2}$. The research dealt only with the spontaneous flora of botanic gardens. In addition, observations were made on plants which had escaped from the gardens and were subsequently found in adjacent areas (Galera 2003 - list of taxa recorded in the years 1992-1999; Galera and Sudnik-Wójcikowska 2004b - the results of floristic analyses).

The total number of ergasiophygophytes (sensu Naegelli and Thellung 1905) recorded in the eight botanic gardens was compared with diversity of alien plants cultivated in the same gardens (from Nowak 1999, 2000). At present a number of hybrids and cultivars are cultivated in botanic gardens. Therefore we compared the following quantitative data:

- the number of taxa at rank lower than genus (i.e. species and subspecific taxa, hybrids and cultivars),

- the number of species and hybrids,

- the number of cultivars.

\section{Data gathering - historical records}

The role of botanic gardens in the development of the alien flora in Central Europe during the last 200 years was determined by an analysis of the literature (over 100 items) and supplemented by information about specimens collected in seven Polish herbaria (KRA, KRAM, KTU, LOD, POZ, WA, WSRL). The area under investigation covered Central Europe (sensu Meusel et al. 1965; Zając 1983), except for the Atlantic province.

In the case of historical records (for a complete list of records see Galera and Sudnik-Wójcikowska 2004a), we considered only those plants (taxa) which had not become established in botanic gardens at the time of investigation:

- ergasiophygophytes - alien plants which spread casually (within and outside the gardens) as a result of the activity of these institutions,

- ephemerophytes that occur specifically in botanic gardens - unintentionally introduced alien weeds (Naegelli and Thellung 1905) associated (at least temporarily) with botanic gardens.
An attempt was also made to reconstruct the early stages of spread of weeds specific to botanic gardens (except for species which soon became ornamentals or useful plants). We chose to investigate weeds (including plants which escaped from cultivation) which fulfil two conditions:

- their diaspores were sent between different botanic gardens,

- there is evidence in modern times of their spontaneous spread (some of the plants spread outside the botanic gardens on a large scale, others remain as weeds growing only in the gardens).

Special attention was paid to the time, site and mode of their introduction to Central Europe. Where possible, we presented the quantitative data (the number of historical records referring to the spontaneous spread of the species in the botanic gardens).

Species groups having a similar history of migration were distinguished. In addition, we created theoretical models illustrating the migration of these groups of plants, which include those phases in the migration process that were associated with the activities of European botanic gardens. Therefore, some of the migration patterns which we proposed do not constitute mathematical rather ecological models (sensu Jäger 1988; Sukopp and Sukopp 1994; Jackowiak 1999). The patterns do not show all the possible migration pathways of species spreading within and outside botanic gardens, but illustrate the migration history of species closely associated with the gardens. These plants had no significant economic value and initially spread across Europe mainly due to the activities of botanic gardens.

\section{RESULTS}

\section{Garden escapes - quantitative data}

\section{Polish botanic gardens (investigations in 1992-1999)}

Over 13000 cultivated taxa at rank lower than genus (species and subspecific taxa, hybrids and cultivars) were recorded in the eight Polish botanic gardens (Nowak 1999, 2000, plants cultivated in greenhouses were not considered in the studies). Not more than 1000 native species and subspecies are grown in Polish gardens. It is estimated, therefore, that about 12000 alien taxa (4300 trees and shrubs) are cultivated in the gardens (Table 1). Such a high number of alien species in cultivation is associated with the specific activities at the botanic gardens, which include the continuous increase of the size of the plant collections.

When the high diversity of species included in the botanic garden collections is considered, the number of plants escaping from cultivation seems relatively low. Field observations made in the eight Polish botanic gardens (from 1992 to 1999) revealed the spontaneous occurrence of 350 taxa (represented 312 species and 27 hybrids; for list of taxa see Galera 2003) not native to Polish botanic gardens which had escaped from cultivation (Table 1). Only 31 alien taxa that had escaped from the botanic gardens to the adjacent area were noted. Only ergasiophygophytes (not established species) which were not cultivated in the vicinity of the investigated gardens were considered. We recorded 28 taxa of herbaceous plants and three species of woody plants outside the botanic gardens. It should be noted that rapid spontaneous encroachment of these plants into 
TABLE 1. The number of alien taxa (at rank lower than genus) escaping from cultivation (investigations from 1992-1999; Galera 2003; Galera and Sudnik-Wójcikowska 2004b) and their contribution to the total number of taxa cultivated in the eight Polish botanic gardens (Nowak 1999, 2000).

\begin{tabular}{lcc}
\hline Selected group of plants (occurring in 8 botanic gardens) & Cultivated plants & Garden escapes \\
\cline { 2 - 3 } & Number of taxa & Number of taxa \\
\hline - all alien vascular plants (taxa at rank lower than genus) & ca. 12000 & 350 \\
- vascular plant cultivars & ca. 6000 & 79 \\
- alien trees and shrubs (taxa at rank lower than genus) & ca. 4300 & 39 \\
\hline
\end{tabular}

new habitats and areas was not observed during the eight years of investigations (Galera 2003).

The flora of Poland contains about 250 species of native trees and shrubs. It can therefore be assumed that among about 4500 taxa of trees and shrubs cultivated in Polish botanic gardens, 4300 taxa are of alien origin (Table 1). Field studies (1992-1999) showed that 39 taxa of alien trees and shrubs (including 36 species and 3 hybrids) were capable of spreading spontaneously within the gardens outside of cultivation (Galera 2003).

\section{Botanic gardens in Central Europe}

(data from the last 200 years)

On the basis of historical data (literature and herbaria) we determined the presence of 185 alien species (including 12 species of trees and shrubs) which were associated with the activities of 53 botanic gardens in Central Europe (see Fig. 1) and four gardens located on the border of Central Europe (Montpellier, Padova, Pavia, Torino, names of cities according to Britannica Atlas, Cleveland 1989). A total of ca. 500 historical floristic records were accumulated (Galera and Sudnik-Wójcikowska 2004a). In addition 15 records of ergasiophygophytes were noted in other parts of the continent (botanic gardens in: Amsterdam, Bordeaux, Budapest, Cluj-Napoca, Coimbra, Debrecen, Jalta, Kew, Madrid, Pecs, Tbilisi).

The investigated botanic gardens, which were explored to a various degree, developed at different periods, and represent areas of different size. In addition their collections contain a different number of taxa. Therefore it is difficult to make a meaningful comparison between the numbers of historical records between these gardens. The highest number of these species was noted in botanic gardens in: Cracow (40 species), Paris (23 species), Wroclaw (17 species), St. Petersburg (15 species), Botanic Garden of University of Warsaw (15 species), Poznan (14 species), BerlinSchöneberg (11 species), and Main Botanic Garden in Moscow (11 species). Only a few species (fewer than 10) were recorded in the remaining 49 Central European gardens (see Fig. 1).

Information about 59 alien species (only herbaceous plants) that had escaped from the gardens to adjacent areas was obtained. In the case of botanic gardens located within the present borders of Poland it was noted that 70 species had escaped from cultivation (including 26 species outside the gardens).

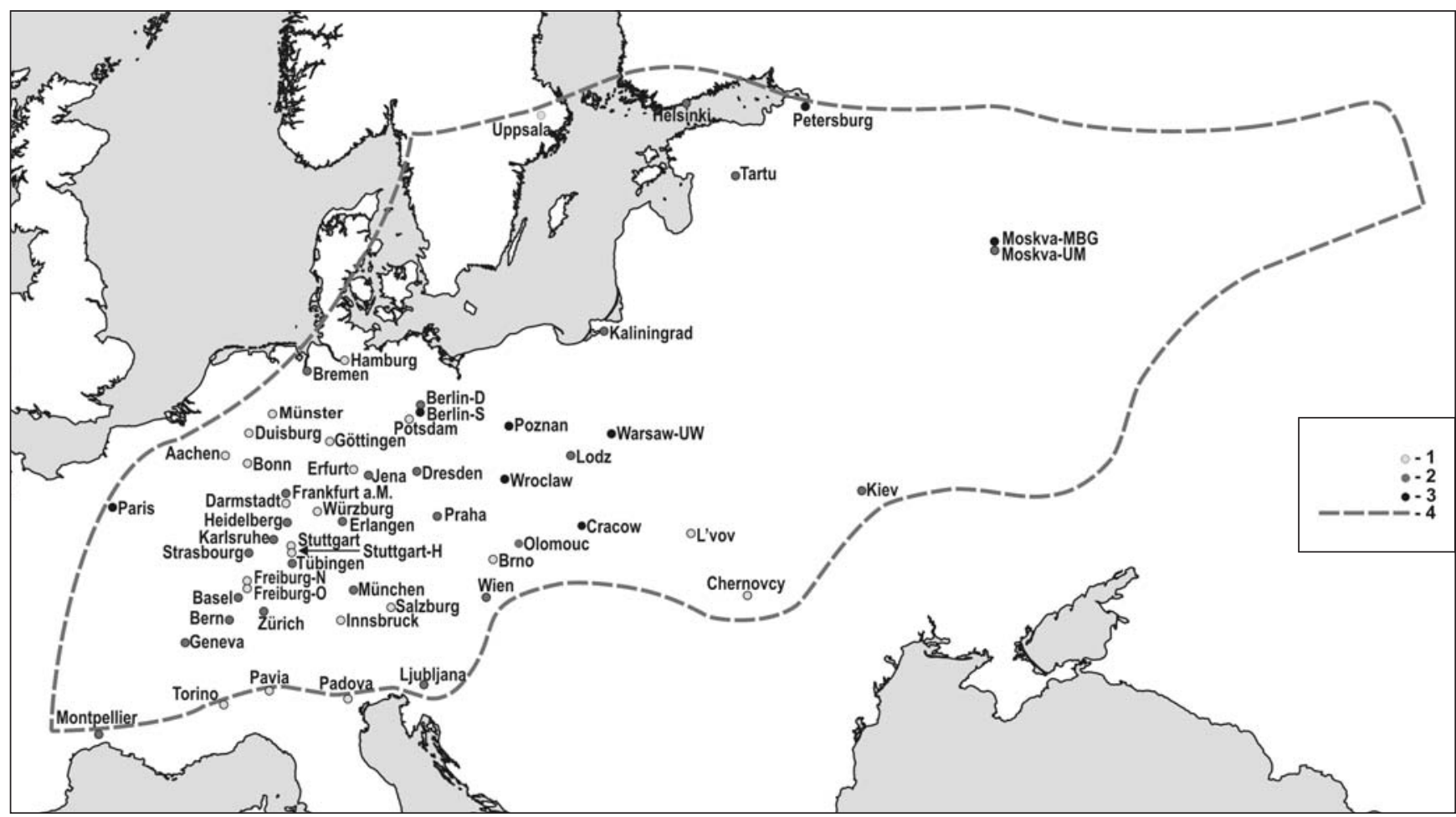

Fig. 1. Historical localities of ergasiophygophytes and ephemerophytes associated with Central European botanic gardens. Legend: 1 - one species recorded in the botanic garden; 2 - from two to ten species recorded in botanic garden; 3 - more than ten species recorded in botanic garden; 4 - borders proposed for Central Europe. Abbreviations: Berlin-D - Botanic Garden Berlin-Dahlem; Berlin-S - Botanic Garden Berlin-Schöneberg; Freiburg-N - new Botanic Garden in Freiburg; Freiburg-O - old Botanic Garden in Freiburg; Moskva-MBG - Main Botanic Garden in Moscow; Moskva-UM - Botanic Garden of Moscow University; Warsaw-UW - Botanic Garden of University of Warsaw; Stuttgart-H - Botanic Garden Stuttgart-Hohenheim (names of cities according to Cleveland 1989). 
The above records come from the last 200 years, therefore, it may be assumed that plants spread outside botanic gardens quite rarely. The data were obtained from various sources and were based on the unsystematic observations by many authors. Moreover, some of the herbarium data are not available today. Therefore, the historical quantitative data should be interpreted with great caution.

An attempt at reconstructing the early history of spread of plants associated with Central European botanic gardens

A qualitative comparative analysis of the historical data (Galera and Sudnik-Wójcikowska 2004a) and the authors' findings (Galera and Sudnik-Wójcikowska 2004b) enabled the selection of a group of species strongly associated with botanic gardens. The reconstruction of the early stages of their dispersal proved difficult, as most of the oldest data regarding the time and direction of transport, as well as place of shipment of diaspores are unavailable today.

Impatiens parviflora DC. [46 historical records from 30 botanic gardens in Central Europe, i.e. 46/30]

An analysis of the variability of the species suggested that all the specimens growing in Europe originated from the same source, as I. parviflora showed a polymorphism in its native region in Asia, whereas the European populations seemed to be homogenous (morphological observations, Trepl 1984). Its seeds were probably introduced to the Botanic Garden in Geneva around 1830. The rapid spread of the plant in Europe was attributed to the shipment and exchange of seeds from the Garden in Geneva (e.g. Graebner 1910; Trepl 1984).

The first record of I. parviflora from Germany dates back to 1837 , where the plant was cultivated in the Botanic Garden in Dresden. Five years later (in 1842) the species became a troublesome weed in some parts of the city (Trepl 1984). Before the species invaded Europe it had been cultivated in many places scattered throughout the continent, which were associated with the specific activities of the European botanic gardens.

\section{Galinsoga parviflora Cav. [34/13]}

G. parviflora was brought to Europe at the end of the 18th century. The diaspores of the plant had been collected during a scientific expedition to Peru. In 1785 the diaspores were sown in Jardin des Plantes in Paris (Thellung 1915) and later in Madrid (probably before 1790; Schulz 1984). Thellung (1915) suggested that "alle oder wenigstens der überwiegende Großteil der europäischen Vorkommnisse von $G$. parviflora (ausgenommen die englischen) von der ehemals in den Pariser Garten eingeführten Cavanillesschen Originalpflanzen abstammen". The species was introduced to Europe again - probably directly from Peru to the botanic garden in Kew in 1796 (Schulz 1984).

By 1800 the sowing material of the plant had been introduced from the Botanic Garden in Paris to Roth's private garden in Vegesack (located just outside Bremen). Subsequently the diaspores were sent to L.C. Treviranus's garden in 1802. Specimens of G. parviflora were found growing spontaneously in the immediate vicinity of these two gardens in 1843 and 1850 (Schulz 1981). At the same time an intensive exchange of diaspores between the gardens (e.g. private and botanic gardens, see Sukopp 2006) was noted. "Die Ausbreitung der Art in Europa setzte zu Beginn des 19. Jh. ein und blieb zunächst im wesentlichen auf
Mitteleuropa beschränkt, wo in der Umgebung mehrerer botanischer Gärten Ausbreitungszentren entstanden [...]" (Schulz 1984).

Ascherson and Graebner (1896-1898) described the species as a troublesome weed in the Berlin-Schöneberg Botanic Garden in 1807. Other authors suggested that G. parviflora had escaped outside the Garden in 1812 (e.g. Braun 1852; Schulz 1984). Fifty years later the plant occurred abundantly in the vicinity of the garden: "Spärlicher auf den Strassen, aber in ganz unsäglicher Menge auf den Feldern, namentlich die Kartoffeläcker fast keine Spur mehr $\mathrm{zu}$ sehen ist [...]“ (Braun 1852). In 1797 the species was introduced into the Botanic Garden in Bremen, from which it escaped massively in 1850 (Sukopp 1990).

G. parviflora escaped from at least 13 European botanic gardens (Galera and Sudnik-Wójcikowska 2004a). The fact that some forms of this species growing in Europe were similar to the herbarium specimens collected during the first expedition to Peru (Schulz 1984) can be attributed to the effective exchange of the sowing material between botanic gardens. This exchange allowed the plant to quickly reach remote parts of Europe.

\section{Galinsoga ciliata (Raf.) S. F. Blake [6/4]}

This species was introduced together with $G$. parviflora from Peru to the Gardens in Paris and Madrid in 1785 or 1790 and later to the Botanic Garden in Kew. G. ciliata was once again introduced from Venezuela in 1840 (Schulz 1984). Literature data suggested that G. ciliata had escaped only from a few botanic gardens. Thus the role of the gardens in this process seemed less important, although both Galinsoga species could have been cultivated with the same frequency. Maitulina (1984) suggested that the species had spread into the natural phytocoenoses of Europe from the Botanic Garden of University of Warsaw. However Gusev (1966) indicated that the species could have been brought to East Europe in many ways and the Botanic Garden in St. Petersburg may have played an important role in the dispersal of the species.

\section{Chamomilla suaveolens (Pursh) Rydb. [16/7]}

This species was introduced to Europe, among others, via the Botanic Garden in Schöneberg in 1845. It escaped from the garden for the first time in 1852 (Braun 1852; Ascherson 1894; Pax 1915). Botanists often indicated a rapid spread of the plant (Braun 1852; Klinge 1882; Abromeit et al. 1903; Gusev 1964). Keller et al. (1935) described in detail the history of the migration of the species in the St. Petersburg region: "in the 1840 s Ch. suaveolens was cultivated as a rare species in the Botanic Garden" (Keller et al. 1935). It spread quickly to become a weed in the 1880 s and since then it has continued to spread to the European part of the former USSR and also further east. Ascherson and Graebner (1898-1899) described a similar scenario of the species migration.

\section{Elodea canadensis Michx. [2/1]}

Although the history of invasion by E. canadensis was associated with the botanic gardens in Europe, the initial invasion stages did not involve the gardens. It is assumed that the plant was introduced to the British Isles with American timber in the first half of the 19th century "but it seems that botanists and botanic gardens were largely re- 
sponsible for the dispersal [of this species] over long distances" (Cook and Urmi-König 1985).

E. canadensis grew vigorously in the Berlin Botanic Garden. In 1859 the garden staff discarded a portion of the living material into a river. This proved to be a turning point in the history of spread of the plant (Kowarik 2003). Intentional (the involvement of the garden staff and aquarium hobbyists) and unintentional (introduction by water transport) human interventions were responsible for the rapid dispersal and successful invasion of the species.

\section{Euphorbia humifusa Willd. and E. maculata L. [65/23 and 45/22]}

E. humifusa "Seit dem Beginn des 19. Jahrhunderts in Botanischen Gärten (Berlin mindestens seit 1813 [...]) gezogen, in denselben oft in Menge verwildert und eingebürgert, ebenso auch (wohl infolge Auswanderns aus den Botanischen Gärten) auf Culturland, an unbebauten Orten, zwischen Pflaster usw. im Europäischen Mittelmeergebiet und in Mittel-Europa" (Ascherson and Graebner 1917). E. maculata may have been introduced into Europe several times. The authors above mentioned two European botanic gardens where the species was grown in the 17 th century - London (before 1660) and Amsterdam (probably in 1689).

It is assumed (Acherson, and Graebner 1917; Zimmermann et al. 1965) that only E. humifusa var. glabra (Thell.) S.Z.Liou occurred in Europe, whereas E. humifusa var. pilosa (Thell.) S.Z.Liou dominated in its native area in Asia. Similar situations were observed in the case of E. macula$t a$ : the typical form, as well as E. maculata var. dentosa Engelm. was noted in North America, but this last variety apparently has not been recorded in Europe so far. Perhaps all the European populations of E. maculata originated from one source, but it is not possible to be certain until genetic studies are performed.

Both Euphorbia species were introduced deliberately but sporadically to botanic gardens at the beginning of their European history of migration (Ascherson and Graebner 1917; Hohla 1998; Röthlisberger 2007). It may be assumed that their presence later in a number of botanic gardens was a result of accidental introductions of the plant, e.g. during transport of soil or sowing material (Hohla 1998). Field observations made in Polish botanic gardens showed that $E$. maculata was unintentionally introduced to the Poznan Botanic Garden from the Botanic Garden in Wroclaw in 1994.

It is interesting to note that the modes and paths of migration of both Euphorbia species (almost identical in shape and life form) which had originated on different continents were similar. In many cases the two species were reported at the same time from the same localities - e.g. in Jardin des Plantes in Paris (Guinet 1936), Geneva (Ascherson and Graebner 1917) and in the Botanic Garden of Jagiellonian University in Cracow, where the first herbarium specimens from Poland were collected in 1864 (Rostański 1992).

Literature data and herbarium collections indicated that both species had occurred (only spontaneously and probably continuously) in the Botanic Garden in Cracow since 1916. E. humifusa was recorded there in 1864, 1916, 1917 , 1926, 1934, 1938, 1939, 1953, 1974, 1976, 1977, 1978 and 1979, whereas E. maculata was noted in 1864, 1912, 1916, 1939, 1953, 1974, 1976, 1977, 1978 and 1979 (Galera, Sudnik-Wójcikowska 2004a). Both species can still be found (Galera 2003) growing in the above garden in the same places as given by Trzcińska-Tacik (1979). A similar scenario was observed for E. humifusa (exhibiting no spreading tendency) in the botanic garden in Switzerland (Röthlisberger 2007).

E. humifusa and E. maculata were encountered in many Central European botanic gardens. Nowadays they escape outside the gardens only in some regions of Europe (e.g. Röthlisberger 2007).

\section{Eragrostis multicaulis Steud. [8/4]}

"In Europe E. multicaulis was brought to a number of botanic gardens as a cultivated plant during the first half of the 19th century, where it subsequently spread on gravel alleys and was found growing between paving stones in the gardens and their immediate vicinities" (Guzik and SudnikWójcikowska 1994). Probably at present the cultivation of the plant has been abandoned (the species is not included in Indices Seminum and Indices Plantarum), but it is still noted in some of the gardens. In the past E. multicaulis was encountered in 4 Polish botanic gardens (the first herbarium specimens were collected from the Botanic Garden of University of Warsaw in 1890 and from the Garden in Wroclaw in 1903 (Galera and Sudnik-Wójcikowska 2004a), where it can still be found growing. However the species was not observed in the immediate vicinities of the above gardens in the years 1992-1999 (Galera 2003). Nevertheless, E. multicaulis was found outside the botanic gardens, but it is difficult to establish where its populations originated from. In the last few years the abundant occurrence of this species has been observed in the alluvia of the Oder River (Kącki 2004, pers. comm.). The current spread of the plant in the centre of Cracow is also notable (J. Guzik, pers. comm.)

\section{Oxalis corniculata L. and O. stricta L. [9/5 and 8/7]}

Both species of Oxalis were apparently accidentally introduced into Central Europe. O. stricta is thought to have arrived from North America in 1658 with potatoes and tobacco, whereas $O$. corniculata was probably introduced with fruit from the Mediterranean region in 1576 (Hantz 1979; Sykora 1990). The former species was introduced into cultivation in the Botanic Garden of Moscow University in 1808 (Kozhevnikov 1935). O. corniculata var. repens f. purpurea Parl. was sometimes cultivated as an ornamental plant (Hegi and Gams 1964). However both species were probably unintentionally introduced in most botanic gardens.

The data obtained by Kozhevnikov (1935), TrzcińskaTacik (1979), Galera and Ratyńska (1999) indicate that the diaspores of $O$. corniculata were accidentally introduced into botanic garden greenhouses. In the Botanic Garden of Moscow University "the plant occurred frequently in greenhouses [...], from where it spread further to flower beds" (Kozhevnikov 1935).

According to Hantz (1979) both species were introduced, probably unintentionally, to Poland, via the Botanic Garden in Wroclaw, during the second half of the 19th century. Oxalis corniculata var. repens had been collected exclusively from the Polish botanic gardens until at least 1979 (Hantz 1979). During the last few years it has been observed more and more frequently and has become naturalized, e.g. in Warsaw in gardens - as a crop weed, and in the streets where it filled spaces between flagstones. 
Veronica peregrina L. [6/4]

The species was accidentally introduced from America to Europe in the 17 th century. The first records of the species date back to 1680 from Great Britain (Hartl, Wagenitz 1975). According to Kozhevnikov (1935) "in Europe $V$. peregrina has become established in several botanic gardens (in Germany, France, Spain, Portugal)".

Of the two forms of $V$. peregrina described in literature, $V$. peregrina f. xalapensis (Hunb., Bonpl., Kunth) Kitag. occurred less frequently and was probably found only in North America (Steyermark 1977; Guzik and Paul 2000). Veronica peregrina $\mathrm{f}$. peregrina was more common in America. In Europe it became naturalized locally, but in Poland the plant is still considered rare. The latter form was reported from six European botanic gardens (Galera and Sudnik-Wójcikowska 2004a - floristic records 19921999, historical records - see Galera 2003). Guzik and Paul (2000) indicated that "in the Botanic Garden [in Cracow] the plant is being eliminated as a weed during cultivation. It is hard to say, whether the species is persisting there since it was found at the end of the 19th century or has been brought here again only recently [...]. It may have been transported to the Botanic Garden with garden soil or imported plant species". Until now $V$. peregrina has not shown a tendency to spread further.

\section{Cuscuta gronovii Willd. ex Schult. [10/4]}

This American species is still rare in Europe, although it was unintentionally introduced to this continent during the second half of the 19th century. It becomes naturalized only locally and it seems not an important crop weed at present in Central Europe (e.g. Galera 2003). The plant was collected and recorded in four European gardens, e.g. in Warsaw (Galera and Sudnik-Wójcikowska 2004a). "Warsaw Botanic Garden does not import the seeds of parasite plants in order to protect the safety of other plants. It may be assumed, therefore, that the seeds of $C$. gronovii were accidentally introduced into the garden" (Szober 1963). The species was observed in the Botanic Garden in Cracow in 1946 (Trzcińska-Tacik 1979) and in 1992-1999 (Galera $2003-C$. gronovii occurs exclusively on plants of the genus Aster). Historical records show that the species was also collected from Callistephus chinensis (L.) Nees, Epilobium hirsutum L. and from a number of plants of American origin (Szober 1963; Trzcińska-Tacik 1979).

Patterns of the migration paths of plant species associated with European botanic gardens

The migration paths of plants associated with the activities of European botanic gardens have some features in common. Thus, it was possible to generate patterns illustrating the early migration stages of these groups of species.

Pattern A presents an invasion of the Impatiens parviflora type: the species was introduced only once into a European botanic garden. Subsequently its diaspores were sent to other gardens throughout Europe. In many places the plant escaped from cultivation to areas outside the botanic gardens. It was recognized, therefore, that all the European populations of I. parviflora came from this one source only (Fig. 2A).

Pattern B differs from pattern $\mathrm{A}$ in that the plants were introduced in Europe several times, e.g. Galinsoga parviflora. The same pattern also illustrates the invasion of $G$. ciliata (the process has proceeded more slowly) and probably that of Chamomilla suaveolens. However no information was available about the number of introductions of $C h$. suaveolens to Europe (Fig. 2B).

Pattern C illustrates the migration path of Elodea canadensis type. The species was accidentally introduced to Europe and subsequently cultivated in botanic gardens. As the species began to spread spontaneously on the continent, the vegetative propagules were sent to different botanic gardens, from which the plant escaped very quickly or was removed by man and continued to spread (Fig. 2C).

Pattern D presents the pathways of migration of Euphorbia humifusa, E. maculata and Eragrostis multicaulis. These species were deliberately introduced to Europe. In the beginning they were cultivated in botanic gardens and therefore reached some of these institutions as a result of intentional introduction. After their cultivation ceased, they still persisted and were even accidentally introduced as weeds in other botanic gardens. In Poland they had a limited tendency (at least so far) to spread outside the gardens. In some countries of Central Europe they were recognized as potentially invasive species (Fig. 2D).

Pattern E was developed for Cuscuta gronovii, Veronica peregrina, Oxalis stricta and $O$. corniculata. These species were not so closely associated with botanic gardens (at least during the first stages of dispersal). They were accidentally introduced to Central Europe. Later they were introduced unintentionally (only a few cases of introduction of $V$. peregrina, Oxalis stricta and $O$. corniculata var. repens f. purpurea to cultivations are known) in European botanic gardens. Eventually, they began to spread spontaneously, which was ascribed to the exchange of contaminated plant material (with diaspores of these species) between the gardens (Fig. 2E). It should be noted that the migration effects varied within this species group. In some cases it was difficult to establish if the species' localities situated outside the gardens exist as a result of the escape of the species from these gardens. Oxalis stricta can be regarded as invasive (at least locally). At present $O$. corniculata is spreading throughout Central Europe, whereas the occurrence of Cuscuta gronovii and Veronica peregrina is still restricted. The above group of species was selected on the basis of the authors' field observations which showed that the plants had persisted in the Polish gardens for several years and spread locally (Galera 2003).

\section{DISCUSSION}

An attempt at assessing the role of botanic gardens in the modification of the local flora

The problem of alien (exotic) plants escaping from cultivation is associated with the activities of botanic gardens. Most of these plants exhibit interesting biological properties but have no economic value. If the plant is not introduced to the commercial market then it is cultivated (practically) only in botanic gardens. Therefore, the exchange of the plant material takes place between these institutions. In this case the botanic gardens are responsible for introducing plants into new habitats. The patterns proposed by us concern such species. The botanic gardens may not play a significant role in the further stages of the migration process of these species. Some of the plants are capable of beco- 
A



B

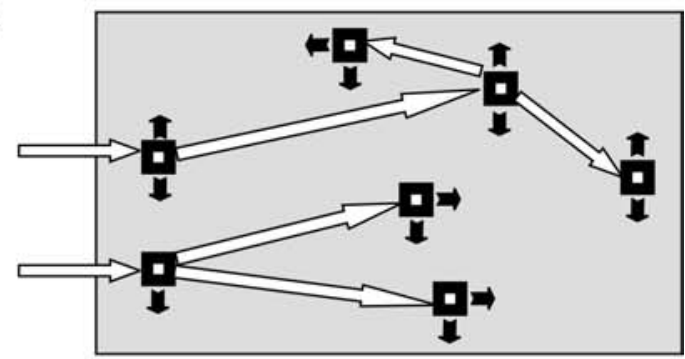

C

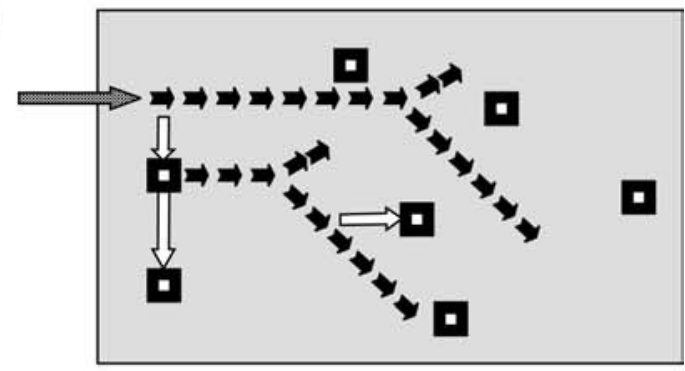

D

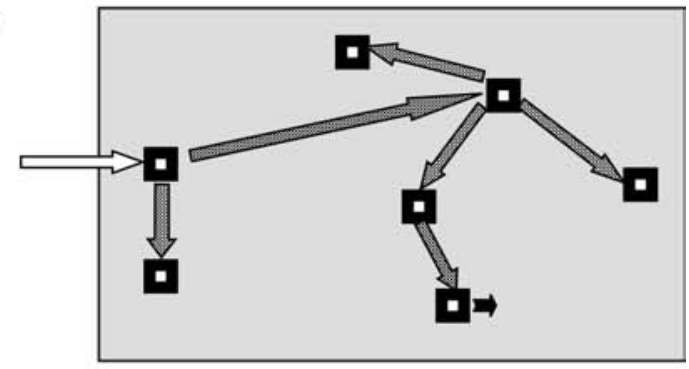

E

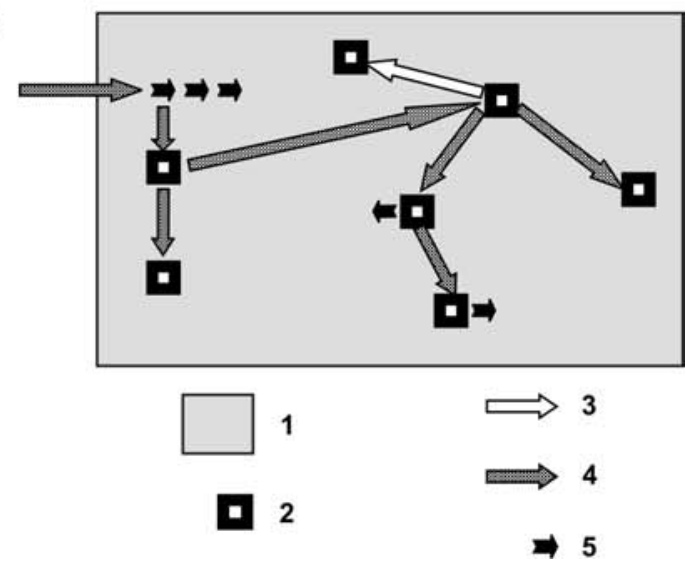

Fig. 2. Examples of migration patterns (A-E) of species associated with botanic gardens.

Legend: 1 - Central Europe; 2 - botanic garden; 3 - intentional introductions; 4 - accidental introductions; 5 - spontaneous spread. ming established in various habitats, others do not spread outside the gardens. Another group of plants is introduced temporarily and eventually disappears. However, the further expansion of these species was not the subject of this study (see e.g. Weber and Gut 2004 and literature cited).

We investigated the role of botanic gardens using quantitative and qualitative analyses. The ten-ten rule (Williamson 1996) can be used to assess the probability of spread of exotic species. This rule is satisfactory for various groups of organisms. The author presents the results from observations made at different time (e.g. Williamson and Fitter 1996). Thus in our case statistical rules can be applied to assess the impacts caused by plants escaping from botanic gardens. Of all the plants cultivated in Polish botanic gardens, only $3 \%$ of the taxa escape from cultivation (Table 1). It is interesting to note that similar results were obtained by Dawnson et al. (2008) for different climatic conditions in tropical Amani Botanical Garden (Tanzania). Out of the 554 alien species planted 100 years ago, 16 species $(3 \%)$ were spreading widely in the Garden out of places of cultivation. These figures seem rather low as it is estimated that around $10 \%$ (between $5 \%$ and $20 \%$ ) of alien species that have been introduced into cultivation are capable of spreading spontaneously (Williamson 1996; Williamson, Fitter 1996; Kowarik 2003). For example, Kowarik (1992b, 1999, 2003) indicated that during the last five centuries 210 from over 3000 species of cultivated trees and shrubs escaped from the gardens (private and botanic gardens) in Brandenburg. The author took into account only taxa of species rank. The plants cultivated in the botanic gardens, however, belong to different cultivars, of which many have limited capability to spread (only $1 \%$ of the cultivars can escape from cultivation, Table 1). It should be noted that a number of authors of floristic works ignore the fact that the plants they recorded were cultivars (e.g. the problem of distinguishing Aquilegia vulgaris L. from cultivars classified as belonging to A. x hybrida hort. by Kowarik 1992a).

Quantitative data indicate that botanic gardens do not pose a serious threat to the flora of Europe (for more information about spontaneous hybridization between plants in ex situ collections and adjacent wild populations - see e.g. Maunder et al. 2004). The 8-year study has shown that nowadays Polish gardens are "enclaves" of high floristic diversity and do not have a great impact on the local flora (in Europe - comp. e.g. Heger 2004; Brandes 2008). Kowarik (2003) suggests that the areas surrounding the gardens (mostly in the city centre) do not contain such a wide range of habitats, hence there is less chance of species escaping from cultivation.

Our quantitative data indicate some interesting trends in the ways the activities of botanical gardens affect the flora of Central Europe. We are aware that the data from the 8 Polish botanic gardens (Galera 2003; Galera and Sudnik-Wójcikowska 2004b) are not fully representative for the whole of Central Europe. Analogical data from other European countries are not available. Quantitative data regarding the diversity of planted species are disputable - e.g. according to Sukopp (2007), about 50000 of plant taxa have been introduced to botanic gardens in Central Europe, but Brandes (2008) has published that ca. 50000 species are planted only in German botanic garden. Database compiled from lists of living collections in the world's botanic gardens concern about 575000 records (BGCI [year unknown]). 
The proposed patterns allow us to analyse qualitatively the initial stages of the distribution process of 10 invasive and potentially invasive species. However, they do not show the further history of spread of these plants. The later stages of their expansion are not associated with the activities of the botanic gardens. An analysis of the floristic data collected during the last 200 years enabled us to formulate a thesis concerning the specific role of botanic gardens in the development of the synanthropic flora in Europe. As a result, a group of species - weeds closely associated with botanic gardens (in the early stages of their expansion) was recognized. Such species as G. parviflora, Galinsoga ciliata, Chamomilla suaveolens, Elodea canadensis, Oxalis stricta and partially $O$. corniculata became invasive in their new habitats (successful invaders). Other species, like $E u$ phorbia humifusa, E. maculata, Eragrostis multicaulis, Veronica peregrina, Cuscuta gronovii are regarded as potentially invasive, at least locally. These species have never been recognized as economically valuable plants in Europe.

Botanic gardens - a network of dispersal centres of species

A number of alien taxa have been introduced into European botanic gardens through the import of exotic plants or the intensive exchange of plant material between gardens (see e.g. the invasion history of Reynoutria japonica Houtt. - Bailey and Conolly 2000). Botanic gardens form a network of collaborating centres, which guarantees a more efficient distribution of diaspores. Only small quantities of diaspores are sent out, which practically prevents their accidental dispersal during transportation (as opposed to forage plants as well as industrial crops and accompanying weeds). Due to this exchange the number of places where plants are cultivated in gardens increased rapidly in different parts of Europe (e.g. Heger 2004; Skvortsov et al. 2005). The migration of species associated with botanic gardens appears to be more or less chaotic (not directional). The dispersal pattern of these species is network-like.

The high spatial heterogeneity of habitats contained within the botanic gardens contributes to the spontaneous spread of species with different ecological requirements (Galera 2003). Greenhouses may play an important role in the dispersal of some plants as well (cf. the history of spread of Oxalis corniculata). Invasions by parasite plants are facilitated through the cultivation of plants from practically all over the world. Therefore the hosts become more easily accessible to invasive parasitic plants. A review of the literature data revealed that Cuscuta gronovii was not highly selective in its choice of host. In the case of host-specific parasites or semi-parasites of alien origin, the presence of a wide variety of plants cultivated in the gardens could play an important role during the early stages of the establishment of the species.

The declining role of botanic gardens as points of introduction of plants

The role of botanic gardens as points of introduction of alien plants has changed over time. The first botanic garden in Padua contained almost exclusively native plants and species which had naturalized before the Middle Ages. During the "Oriental period" (1560-1620) plants were introduced into West European botanic gardens from the Near East, South and South-East Europe (Sykora 1990). At the same time a number American plants were introduced to
European botanic gardens. The assortment of species cultivated in the European botanic gardens has changed radical1y. The gardens have been engaged in the import of a large number of alien species. During the second half of the 20th century, intensive plant breeding programmes were conducted, which gave rise to many new cultivars.

During this period there was an increasing emphasis on the conservation of native flora and the preservation of some plants in the policy and mission statements of botanic gardens (e.g.: Heywood 1987, 1989; Maunder 1994; Maunder et al. 2001; BGCI [year unknown]). Therefore, the role of Polish gardens has changed as well. In the last few years these institutions have played a less important role in popularizing new cultivars by limiting the distribution of the plants through free international exchange of the plant material (Zemanek 1993; Węglarski 1997; Puchalski and Galera 2001).

During the last few decades many garden centres and other outlets that operate on a larger scale have opened, and these produce, export and import plants for commercial use (e.g. Dehnen-Schmutz et al. 2007). In the 20th century the number of plants cultivated in Poland increased markedly (e.g. Marosz 2002 and Marcinkowski 2003). It is estimated that in the last few years about 7500 garden plant taxa that are available on the Polish market have been grown outdoors (industrial crop varieties, e.g. cereals and oil plants, were not considered). These include mainly varieties of ornamental plants: about 5000 taxa of trees and shrubs (see e.g. Marosz 2002 and 2005, Związek Szkółkarzy Polskich 2007), 1500 taxa of perennials (Marcinkowski 2003) as well as 1000 annual and biennial herbs (see SGVegetables.com 2006). The number of edible plants (industrial plants are not included) is relatively small. For example, the Plantico company sells over 320 cultivars of vegetables (see PlantiCo Zielonki 2007), whereas The Polish Nurserymen Association offers 240 taxa of fruit trees and shrubs (see Związek Szkółkarzy Polskich 2007).

The number of cultivated plants offered for sale in Poland is much lower than the number of plants making up the botanic garden collections (7500 and 12000 taxa, respectively). It should be noted, however, that the distribution network of garden centres has expanded considerably and is more efficient nowadays (see: Polskie Stowarzyszenie Centrów Ogrodniczych 2009) than the free exchange of plant material between botanic gardens. These dynamically operating garden centres form a well-developed distribution network and offer a rich assortment of garden plants (particularly cultivars, see e.g. Związek Szkółkarzy Polskich 2007). Botanic gardens sometimes obtain plant material from these centres for their collections. Thus more and more cultivars whose reproduction ability is limited can be found growing in the gardens.

Botanic gardens still play some role in popularizing rare and new cultivated plants. Once the species is introduced to a world-wide market the importance of these institutions decreases. It is expected that the exchange of plants will become more intense in the future (in spite of international conventions and agreements, regional directives and phytosanitary regulations, horticultural commerce of ornamental plants as the source of plant invaders - see e.g. Peters et al. 2006). However the role of botanic gardens in this process will be relatively small. The policy of the European Botanic Gardens Consortium is aimed at reducing the risk of 
alien plant escape and invasion from cultivation (see Sharing information, and policy, on potentially invasive alien plants in Botanic Gardens 2009).

The results of the 8-year research indicated that during this short period Polish botanic gardens seemed to have had little impact on the flora of the local flora. Historical data concerning Central Europa (from the last 200 years) indicate that in the past these institutions were points of introduction and spread of some invasive plants. It should be noted, however, that botanic gardens were not the only source of invasive species. They played a vital role in the spread of invaders only in their initial stages of migration.

\section{ACKNOWLEDGMENT}

The study was supported by the Ministry of Science and Higher Education (grant number 6 P04 037 20).

\section{LITERATURE CITED}

ABROMEIT J., JENTSCH A., VOGEL G. 1903. Flora Ost und Westpreussen, Vol. 2.1. Preussischer Bot. Ver. Kšnigsberg, Verl. R. Friedlander et Sohn, Berlin.

ADAMCZEWSKA A., BOMAROWSKA A., JANOWSKA J. 2000. Flora synantropijna Ogrodu Botanicznego w Łodzi. Acta Univ. Lodz., Folia Bot. 15: 115-130. (in Polish with English summary)

ASCHERSON P. 1894. Die verwilderten Pflanzen in der Mark Brandenburg. Ein Beitrag zur Geschichte der Pflanzen. Z. Gesammten Naturwiss. 8: 435-463.

ASCHERSON P., GRAEBNER P. 1896-1898. Synopsis der MitteleuropŠischen Flora, Vol. 1. Verl. W. Engelmann, Leipzig.

ASCHERSON P., GRAEBNER P. 1898-1899. Flora des Nordostdeutschen Flachlandes. Verl. Gebrźder Borntraeger, Berlin.

ASCHERSON P., GRAEBNER P. 1917. Synopsis der MitteleuropŠischen Flora, Vol. 7. Verl. W. Engelmann, Leipzig.

Bailey I.P., conolly A.p. 2000. Prize-winners to pariahs. A history of Japanese Knowtweed s.l. (Polygonaceae) in the British Isles. Watsonia 23: 93-110.

BGCI [year unknown] [on line]. Acc.: 2009-06-25 from: <http// www.bgci.org/plant_search.php>.

BORYSIAK J., JAŃCZYK-WĘGLARSKA J., KOŃCZAL J. 2004. Spontaniczna flora naczyniowa i roślinność Ogrodu Botanicznego Uniwersytetu im. A. Mickiewicza oraz możliwości ich wykorzystania w dydaktyce. In: Przyroda Polski w europejskim dziedzictwie dóbr natury. Streszczenia referatów i plakatów. 53 Zjazd Polskiego Towarzystwa Botanicznego, Toruń, Bydgoszcz, 6-11 września 2004. Polskie Towarzystwo Botaniczne, Oddział Bydgoski, Oddział Toruński, Wydaw. Uczelniane ATR, Toruń-Bydgoszcz, p. 144. (in Polish)

BRANDES D. 2008. Invasive Pflanzen: Naturkatastrophe oder Spiegel unserer Kulturgeschichte? Abh. Braunschw. Wissensch. Ges. 59: 9-36.

BRAUN A. 1852. Chamomilla discoidea Gay, eine neue Wanderpflanze in Deutschland. Bot. Zeitung 10.38: 649-653.

CLEVELAND W.A. (ed.) 1989. Britannica Atlas. Encyclopedia Britannica, Chicago, Auckland, Geneva, London, Madrid, Manila, Paris, Rome, Seoul, Sydney, Tokyo, Toronto.

COOK C.D.K., URMI-KÖNIG K. 1985. A revision of the genus Elodea (Hydrophyllaceae). Aquatic Bot. 21: 111-156.

DAWSON W., MNDOLWA A.S., BURSLEM D.F.R.P., HULME P.E. 2008. Assessing the risks of plant invasions arising from collections in tropical botanic gardens. Biodivers. Conserv. 17: 1979-1995.
DEHNEN-SCHMUTZ K., TOUZA J., PERRINGS C., WILLIAMSON M. 2007. A century of the ornamental plant trade and its impact on invasion success. Diversity Distrib. 13: 527-534.

EVTJUCHOVA M.A. 1949. Flora i rastiteĺnost' territorii Glavnogo botaničeskogo sada. Trudy Glavn. Bot. Sada 1: 63-86.

GALERA H. 2003. Rośliny występujące spontanicznie w polskich ogrodach botanicznych - przegląd listy florystycznej. Biul. Ogr. Bot. Muz. Zbiorów 12: 31-82.

GALERA H., RATYŃSKA H. 1999. Greenhouse weeds in the Botanical Garden of PAS in Warsaw-Powsin. Acta Soc. Bot. Pol. 68.3: 227-236.

GALERA H., SUDNIK-WÓJCIKOWSKA B. 2004a. Historyczne notowania chwastów związanych z działalnością ogrodów botanicznych Europy Centralnej. Fragm. Flor. Geobot. Polonica 11.2: 293-317. (in Polish with English summary)

GALERA H., SUDNIK-WÓJCIKOWSKA B. 2004b. The structure and differentiation of the synanthropic flora of the botanical gardens in Poland. Acta Soc. Bot. Pol. 73.2: 121-128.

GRAEBNER P. 1910. Lehrbuch der allgemeinen Pflanzengeographie. Verl. Uelle und Meyer, Leipzig.

GRAF A., ROHNER M.-S. 1984. Wiesen im Botanischen Garten Berlin-Dahlem. Verh. Berl. Bot. Ver. 3: 3-23.

GUINET C. 1936. Contribution a' l'Žtude de la flore adventice de la region parisienne. Bull. Soc. Bot. France 83: 225-234.

GUSEV YU.D. 1964. Naturalizatsiya amerikanskikh rastenii v basseine Finskogo zaliva. Bot. Zh. 49.9: 12-62.

GUSEV YU.D. 1966. Rasselenie vidov Galinsoga v Leningradskoi oblasti. Bot. Zh. 51.4: 577-579.

GUZIK J., PAUL W. 2000. Veronica peregrina (Scrophulariace$a e$ ) in Kraków - rediscovered after a century. Fragm. Flor. Geobot. 45.1-2: 513-539.

GUZIK J., SUDNIK-WÓJCIKOWSKA B. 1994. Nowe lub rzadkie w Polsce rośliny synantropijne. 1. Eragrostis multicaulis (Poaceae). Fragm. Flor. Geobot., Ser. Pol. 1: 209-221. (in Polish with English summary)

HANTZ J. 1979. Rodzaj Oxalis L. w Polsce. Fragm. Flor. Geobot. 25.1: 65-112. (in Polish)

HARTL D. 1975. Familie Scrophulariaceae. In: Illustrierte Flora von Mitteleuropa. Hartl D., Wagenitz G. (eds). P. Parey Verl., Berlin-Hamburg, Vol. 6.1, pp. 1-469.

HEGER T. 2004. Zur Vorhersagbarkeit biologischer Invasionen. Entwicklung und Anwendung eines Modells zur Analyse der Invasion gebietsfremder Pflanzen. Neobiota 4: 1-197.

HEGI G., GAMS H. 1964. Illustrierte Flora von Mitteleuropa, Vol. 4.3. C. Hanser Verl., München.

HEYWOOD V.H. (ed.) 1989. The Botanic Gardens Conservation Strategy. IUCN Bot. Gard. Conservation Secretariat, KewRichmond.

HEYWOOD V.H. 1987. The changing role of the botanic garden. In: Botanic gardens in the World Conservation Strategy. Bramwell D., Hamann O., Heywood V.H., Synge H. Acad. Press, London, pp. 117-130.

HOHLA M. 1998. Euphorbia maculata L., die Flecken-Wolfsmilch, jetzt auch im Innviertel (Oberösterreich). Beitr. Naturk. Oberösterreichs 6: 303-307.

JACKOWIAK B. 1999. Modele ekspansji roślin synantropijnych i transgenicznych. Phytocoenosis 11, Semin. Geobot. 6: 3-14. (in Polish)

JÄGER E. 1988. Möglichkeiten der Prognose synanthroper Pflanzenausbreitungen. Flora 180: 101-131.

KELLER B.A., LYUBIMENKO V.N., MAL'TSEVA A.I., FEDRENKO B.A., SHISHKINA B.K., KAMENSKII K.B., IL'IN M.M. 1935. Sornye rasteniya SSSR , Vol. 4. Izd. Akademi Nauk SSSR, Moskva-Leningrad.

KLINGE J. 1882. Flora von Est-, Liv- und Curland. Verl. F. Kluge, Reval.

KOWARIK I. 1992a. Berücksichtigung von nichtheimischen Pflanzenarten, von "Kulturflüchtlingen" sowie Pfanzenvorkommen auf Sekundärstandorten bei der Aufstellung Roter Listen. Schriftenreihe Vegetationsk. 23: 175-190. 
KOWARIK I. 1992b. Einführung und Ausbreitung nichtheimischer Gehölzarten in Berlin und Brandenburg und ihre Folgen für Flora und Vegetation. Verh. Bot. Ver. Berlin, Brandenburg 3: 3-188.

KOWARIK I. 1999. Neophyten in Deutschland: quantitativer Überblick, Eiführungs- und Verbeitungswege, ökologische Folgen und offene Fragen. Umweltbundesamt Texte 55/99: 17-43.

KOWARIK I. 2003. Biologische Invasionen: Neophyten und Neozonen in Mitteleuropa. Verl. E. Ulmer, Stuttgart.

KOZHEVNIKOV A.V. 1935. Sornaya i adventivnaya flora Moskovskogo bot. sada. Byull. Moskovsk. Obshch. Isp. Prir., Otd. Biol. 44.4: 193-203.

MAITULINA YU.K. 1984. Novye i redkie adventivnye rasteniya Vologodskoi oblasti. Byul. Glavn. Bot. Sada 132: 45-46.

MARCINKOWSKI J. 2003. Zmiany w asortymencie krajowych szkółek bylinowych. Szkółkarstwo 6: 22-26. (in Polish)

MAROSZ A. 2002. Asortyment drzew i krzewów w polskich szkółkach. Szkółkarstwo 6: 26-29. (in Polish)

MAROSZ A. 2005. Stan i perspektywy produkcji róż w Polsce. In: Problemy w produkcji krzewów róż w nowych warunkach ekonomicznych po akcesji z Unią Europejską. Czernyczewicz E., Konopiński M. (eds). Konferencja Naukowa Akademii Rolniczej, Lublin, 2005.02.16. Katedra Ekonomiki Ogrodnictwa Akademii Rolniczej, Lublin, pp. 4-12. (in Polish)

MAUNDER M. 1994. Botanic gardens: future challenges and responsibilities. Biodivers. Conserv. 3: 97-103.

MAUNDER M., HIGGENS S., CULHAM A. 2001. The effectiveness of botanic garden collections in supporting plant conservation: a European case study. Biodivers. Conserv. 10: 383-401.

MAUNDER M., HUGHES C., HAWKINS J.A., CULHAN A. 2004. Hybridization in ex situ plant collections: conservation concerns, liabilities, and opportunities. In: Hybridization in ex situ plant collections: conservation concerns, liabilities, and opportunities. Guerrant E. O., Havens K., Maunder M. (eds). Island Press, Washington, Corelo, London, p. 325-364.

MEUSEL H., JÄGER E., WEINERT E. 1965. Vergleichende Chorologie der zentraleuropäischen Flora. G. Fischer Verl, Jena.

NAEGELLI D., THELLUNG A. 1905. Die Flora des Kantons Zürich. Die Ruderal- und Adventivflora des Kantons Zürich. Viertelj. Schr. naturf. Ges., Zürich 50: 225-305.

NOWAK T.J. (ed.) 1999. Index Plantarum polskich kolekcji dendrologicznych. Pr. Ogr. Bot. Uniw. Wrocł. 5.1: 17-306. (in Polish with English summary)

NOWAK T.J. (ed.) 2000. Index Plantarum of outdoors cultivated herbaceous plants in Poland. Pr. Ogr. Bot. Uniw. Wrocł. 6.1: 5-399.

PAX F. 1915. Schlesiens Pflanzenwelt. Verl. G. Fischer, Jena.

PETERS W.L., MEYER M.H., ANDERSON N.O. 2006. Minnesota horticultural industry survey on invasive plants. Euphytica 148: 75-86.

PLANTICO ZIELONKI 2007 [on line]. Acc.: 2008-01-25 from: $<$ http://www.plantico.pl/index.php?option=com_content\&task=view\&id=16\&Itemid=77>. (in Polish)

POLSKIE STOWARZYSZENIE CENTRÓW OGRODNICZYCH 2009 [on line]. Acc.: 2009-06-08 from: <http://www. psco.org.pl/index.php?body=firmy\&woj=all>. (in Polish)

PUCHALSKI J., GALERA H. 2001. Zadania dla polskich ogrodów botanicznych w zakresie ochrony roślin w skali europejskiej zgodnie z Konwencją Berneńską. Biul. Ogr. Bot., Muzeów i Zbiorów 10: 85-94. (in Polish with English summary)

REICHARD S.H., WHITE P. 2001. Horticulture as a pathway of invasive plant introductions in the United States. BioScience 51, 2: 103-113.

ROSTAŃSKI K. 1992. Euphorbia L., Wilczomlecz. In: Flora Polski. Jasiewicz A. (ed.). Instytut Botaniki im. W. Szafera, Polska Akademia Nauk, Kraków, Vol. 3, pp. 140-168. (in Polish)

RÖTHLISBERGER J. 2007. Aktuelle Verbreitung der Gattung Chamaesyce (Euphorbiaceae) in der Schweiz. Bauhinia 20: 19-33.
SCHULZ D.L. 1981. Untersuchungen zur Typisierung der peruanischen Galinsoga-Arten. Feddes Repert. 92.5-6: 387-395.

SCHULZ D.L. 1984. Zur Ausbreitungsgeschichte der GalinsogaArten in Europa. Acta Bot. Slov., Ser. A, Suppl. 1: 285-296.

SG-VEGETABLES.COM 2006 [on line]. Acc.: 2008-01-25 from: <http://www.sg-vegetables.com/pl/assortment.asp>. (in Polish)

SHARING INFORMATION, AND POLICY, ON POTENTIALLY INVASIVE ALIEN PLANTS IN BOTANIC GARDENS 2009. Acc.: 2009-06-25 from: <http://www.plantnetwork.org /aliens/index.html>

SKVORTSOV A.K., VINOGRADOVA YU.K., KUKLINA A.G., KRAMARENKO L.A., KOSTINA M.V. 2005. Formirovanie ustoichivykh introduktsionnykh populyatsii. Abrikos, chereshnya, cheremukha, zhimolost', smorodina, aroniya. Nauka, Moskva.

STEYERMARK J.A. 1977. Flora of Missouri. The Iowa State Univ. Press, Iowa.

SUKOPP H. 1990. Stadtökologie: das Beispiel Berlin. D. Reimer Verl., Berlin. (in German)

SUKOPP H. 2006. Botanische Gärten und die Berliner Flora. Willdenowia 36: 115-125.

SUKOPP H. 2007. Dynamik und Konstanz in der Kulturlandschaftentwicklung. Berlin-Brandenbg. Akad. Wiss. Ber. Abh. 13: 13-34.

SUKOPP H., SUKOPP U. 1994. Das Modell der Einführung und Einbürgerung nicht einheimischer Arten. Gaia. Ecol. Perspec. in Science, Humanities and Economics: 267-288.

SYKORA K.V. 1990. History of the impact of man on the distribution of plant species. In: Biological Invasions in Europe and the Mediterranean Basin. Di Castri F., Hansen A.J., Debussche M. (eds). Kluwer Acad. Publ., Dortrecht, pp. 37-50.

SZOBER J. 1963. Ukazanie się kanianki amerykańskiej w Warszawskim Ogrodzie Botanicznym. Wiad. Bot. 7.1: 70-71. (in Polish)

THELLUNG A. 1915. †ber die in Mitteleuropa vorkommenden Galinsoga-Formen. Allg. Bot. Z. Syst. 1-4: 1-16.

TREPL L. 1984. Über Impatiens parviflora DC. als Agriophyt in Mitteleuropa. Diss. Bot. 73: 1-398.

TRZCIŃSKA-TACIK H. 1979. Flora synantropijna Krakowa. Rozpr. habil. UJ, Kraków 32: 1-278. (in Polish)

Weber E., gut D. 2004. Assessing the risk of potentially invasive plant species in central Europe. J. Nature Conserv. 12: 171-179 .

WEGLARSKI K. 1997. Active protection as an important element of the genus diversity of rare and endangered flora species. Idee ekologiczne 10, Ser. Szkice 6: 27-34.

WILLIAMSON M. 1996. Biological invasions. Chapman and Hall, London-Wienheim-New York-Tokyo-Melbourne-Madras.

WILLIAMSON M., FITTER A. 1996. The varying success of invaders. Ecology 77, 6: 1661-1666.

WITTIG, R. 2002: Siedlungsvegetation. E. Ulmer Verl., Stuttgart.

ZAJAC A. 1983. Studies on the origin of archaeophytes occuring in Poland. Part 1. Methodical considerations. Zesz. Nauk. UJ, Pr. Bot. 11: 87-107.

ZEMANEK B. 1993. The role of botanical gardens in the development of scientific study of plants. Polish Bot. Stud., Guidebook Ser. 9: 11-20.

ZIMMERMANN W., HEGI G., BEGER H. 1965. Fam. Euphorbiaceae. In: Illustrierte Flora von Mitteleuropa. Hegi G. (ed.). C. Hanser Verl., München, Vol. 5.1, pp. 113-190.

ZWIAZEK SZKÓŁKARZY POLSKICH 2007 [on line]. Acc.: 2008-01-25 from: <http://www.zszp.pl/index.php?sub=szukaj\&adv=0\&ltr=A\&grp=1\&prez=1>. (in Polish, English, Russian) 